Cleve Clin J Med. 2015 January ; 82(1): 49-63. doi:10.3949/ccjm.82a.140002.

\title{
Selecting antithrombotic therapy for patients with atrial fibrillation
}

\author{
CHRISTINE TANAKA-ESPOSITO, MD and \\ Section of Pacing and Cardiac Electrophysiology, Department of Cardiovascular Medicine, Heart \\ and Vascular Institute, Cleveland Clinic
}

MINA K. CHUNG, MD

Section of Pacing and Cardiac Electrophysiology, Department of Cardiovascular Medicine, Heart and Vascular Institute, Cleveland Clinic

\begin{abstract}
When considering anticoagulant therapy for patients with atrial fibrillation, one must balance the reduction in risk of thromboembolism that this therapy offers against the risk of bleeding that it poses. The American Heart Association, American College of Cardiology, and Heart Rhythm Society updated their atrial fibrillation guidelines in 2014. This review outlines a rationale for clinical decision-making based on the new guidelines and summarizes the currently approved drugs.
\end{abstract}

Antithrombotic therapy reduces the risk of systemic embolism in patients with atrial fibrillation, but one approach does not suit all patients. The decision whether to start this therapy—and which agent to use-must take into account the patient's risk of thromboembolism as well as bleeding.

Antithrombotic therapy encompasses anti-platelet drugs such as aspirin and clopidogrel and anticoagulants such as warfarin and the target-specific oral anticoagulants (TSOACs). Oral anticoagulation is more effective than antiplatelet therapy and is preferred in all but those at lowest risk, in whom either antiplatelet therapy or no therapy is deemed adequate.

Patients with valvular atrial fibrillation, specifically those who have rheumatic mitral stenosis or a prosthetic heart valve, are at significantly higher risk of systemic embolization. Their overall risk-benefit profile is nearly always in favor of anticoagulation. But the same is not necessarily true for patients with nonvalvular atrial fibrillation.

The following discussion sets forth our rationale for clinical decision-making, based on recommendations in the 2014 guidelines from the American Heart Association, American College of Cardiology, and Heart Rhythm Society. ${ }^{1}$ The second half of this review outlines the oral anticoagulants currently available.

ADDRESS: Mina K. Chung, MD, Heart \& Vascular Institute, J2-2, Cleveland Clinic, 9500 Euclid Avenue, Cleveland, OH 44195; chungm@ccf.org. 


\section{ONE IN FOUR PEOPLE}

Atrial fibrillation is common, with an incidence that increases with age. It affects more than $10 \%$ of people over age 80 and is often associated with cardiovascular disease. ${ }^{2}$ Based on Framingham Heart Study data, a person's lifetime risk of developing it is about $25 \%$. $^{3}$

\section{FIVEFOLD RISK OF STROKE}

The most serious complication of atrial fibrillation is arterial thromboembolism, of which ischemic stroke is the most common and most feared manifestation. The risk of stroke is five times higher than normal in patients with atrial fibrillation. ${ }^{3}$ More than $15 \%$ of strokes may be attributable to atrial fibrillation, and the proportion increases with age. ${ }^{4}$

The risk of thromboembolism appears to be similar in patients with clinically manifest atrial fibrillation irrespective of the type (paroxysmal, persistent, or permanent). The Stroke Prevention in Atrial Fibrillation (SPAF) study ${ }^{5}$ and the Atrial Fibrillation Clopidogrel Trial With Irbesartan for Prevention of Vascular Events (ACTIVE W) ${ }^{6}$ showed that patients who had paroxysmal atrial fibrillation and at least one risk factor for thromboembolism had stroke rates comparable to those of their counterparts who had persistent and permanent atrial fibrillation.

Subclinical atrial fibrillation may be an important cause of stroke. Clinically silent episodes can be detected by implantable electronic devices, which record episodes of atrial tachyarrhythmia (atrial high-rate events). Subclinical episodes have been detected in $10 \%$ to $28 \%$ of monitored patients who did not have a history of atrial fibrillation. ${ }^{7,8}$ Patients who have atrial high-rate events detected by implantable devices have a higher risk of future clinically manifest atrial fibrillation, thromboembolic events, or both. ${ }^{7-9}$ Yet characteristics of atrial high-rate episodes that predict risk are not well defined and warrant further investigation.

\section{CLINICAL RISK FACTORS FOR STROKE}

To date, thousands of patients with nonvalvular atrial fibrillation have participated in randomized clinical trials of stroke prevention. The placebo groups from these trials provide a sizable database for retrospectively identifying clinical characteristics associated with thromboembolism. The Atrial Fibrillation Investigators ${ }^{10}$ pooled data from five large trials and found that risk factors consistently associated with stroke in multivariate analysis included diabetes mellitus, hypertension, prior systemic embolism, and advanced age.

Though the risk of stroke increases with age with no lower limit, most studies identify age 65 as a threshold, with further escalating risk after age 75. Moreover, women were observed to be at higher risk in some but not all studies. These risk factors have become components of commonly used risk-stratification schemes.

\section{Hypertrophic cardiomyopathy}

Maron et a ${ }^{11}$ reported that atrial fibrillation in patients with hypertrophic cardiomyopathy was independently associated with thromboembolism. In 900 patients with hypertrophic 
cardiomyopathy, the prevalence of systemic embolism was $6 \%$. Patients with hypertrophic cardiomyopathy and a thromboembolic complication were seven times more likely to have atrial fibrillation than matched counterparts free of thromboembolism. A notable subset of patients experienced a stroke or embolic event before age 50, and the authors advised that the risk of thromboembolism should be considered in patients of any age with hypertrophic cardiomyopathy and atrial fibrillation.

Olivotto et al ${ }^{12}$ similarly found patients with hypertrophic cardiomyopathy and atrial fibrillation to be at significantly greater risk of stroke (odds ratio [OR] 17.7, 95\% confidence interval $[\mathrm{CI}] 4.1-75.9, P<.001)$.

Chronic kidney disease is also associated with a higher risk of thromboembolism in patients with atrial fibrillation. A glomerular filtration rate of $60 \mathrm{~mL} / \mathrm{min}$ or less is independently and inversely predictive of risk. ${ }^{13,14}$

While patients with end-stage renal disease have been largely excluded from stroke prevention trials, Vázquez et $\mathrm{al}^{15}$ prospectively followed 190 dialysis patients for 12 months. In multivariate analysis, compared with matched controls without documented atrial fibrillation, patients receiving renal replacement therapy and having any form of atrial fibrillation were eight times more likely to have systemic embolization.

\section{IMAGING-BASED RISK FACTORS}

In addition to clinical factors, several imaging-based factors have been associated with stroke risk in patients with atrial fibrillation.

Complex aortic atheroma or markers of blood stasis within the left atrium, such as reduced left atrial appendage emptying flow $(<20 \mathrm{~cm} / \mathrm{second})$, dense spontaneous echo contrast, or left atrial appendage thrombus, seen on transesophageal echocardiography, were independently associated with increased systemic embolic risk in the third SPAF substudy. ${ }^{16}$ Moreover, multivariate analysis of SPAF data found both left ventricular dysfunction of any severity and increased left atrial size (diameter corrected for body surface area by M-mode > $2.5 \mathrm{~cm} / \mathrm{m}^{2}$ ) to be independent predictors of thromboembolism. ${ }^{17}$

Although enlargement of the left atrium has not been incorporated into traditional risk stratification schemes, data from Osranek et a ${ }^{18}$ further implicate it as a marker of risk. The cohort was small $(\mathrm{N}=46)$, but consisted of patients with lone atrial fibrillation followed for nearly 30 years. Patients with normal left atrial size enjoyed a benign course, while those with left atrial enlargement $\left(>32 \mathrm{~mL} / \mathrm{m}^{2}\right)$ at diagnosis or later during follow-up had significantly worse event-free survival (hazard ratio [HR] 4.46, 95\% CI 1.56-12.74, $P<$. 01). All embolic strokes occurred in the group with left atrial enlargement.

\section{RISK STRATIFICATION SCHEMES}

Several models for predicting systemic embolism risk in patients with nonvalvular atrial fibrillation have been proposed and validated. 
The CHADS $_{2}$ score has been the most widely applied, being simple to use. ${ }^{19,20}$ It assigns 1 point each for Congestive heart failure, Hypertension, Age 75 or older, and Diabetes, and 2 points for prior Stroke or systemic thromboembolism.

In patients with chronic nonvalvular atrial fibrillation, Gage et al ${ }^{19}$ reported that the stroke rate was lowest in those with a score of 0 , with an annual adjusted stroke rate of $1.9 \%$ per year, and highest in those with the maximal possible score (ie, 6), with a rate of $18.2 \%$. The rate increased by a factor of 1.5 with each point in the $\mathrm{CHADS}_{2}$ score.

$\mathrm{CHA}_{\mathbf{2}} \mathrm{DS}_{\mathbf{2}}$-VASc-Endorsed for use in both the American and European guidelines, ${ }^{1,21}$ $\mathrm{CHA}_{2} \mathrm{DS}_{2}$-VASc is an extension of $\mathrm{CHADS}_{2}$. Points are assigned as follows:

- Congestive heart failure or left ventricular dysfunction (moderate to severe left ventricular dysfunction or recent heart failure exacerbation requiring hospitalization irrespective of ejection fraction): 1 point

- Hypertension: 1 point

- Age 275: 2 points; age 65-74: 1 point

- Diabetes mellitus: 1 point

- Stroke, transient ischemic attack, or thromboembolism: 2 points

- Vascular disease (prior myocardial infarction, peripheral arterial disease, or aortic plaque): 1 point

- Sex, female: 1 point

- Maximum score: 9 points.

Low risk is defined as a score of 0 for a man or, for a woman with no other risk factors, 1 . A score of 1 for a man indicates moderate risk, and a score of 2 or more is high risk. Lip et al ${ }^{22}$ found that, in untreated patients with nonvalvular atrial fibrillation, rates of stroke ranged from 0 with a score of 0 to $15.2 \%$ per year with a score of 9 points.

In a large cohort with over 11,000 patient-years of follow-up, 98\% of the thromboembolic events occurred in people with a $\mathrm{CHA}_{2} \mathrm{DS}_{2}$-VASc score of 2 or more. Moreover, more than $99 \%$ of patients with a score of less than 2 were free of stroke and thromboembolism. ${ }^{23}$

Compared with the $\mathrm{CHADS}_{2}$ score, $\mathrm{CHA}_{2} \mathrm{DS}_{2}$-VASc has superior negative predictive power. Of 1,084 patients from the European Heart Survey for Atrial Fibrillation, the newer scheme classified significantly fewer patients as being at either low risk (score of $0 ; 9 \%$ vs $20 \%$ ) or intermediate risk (score of $1 ; 15 \%$ vs $35 \%$ ). ${ }^{23}$ Though the overall rate of stroke was low, those categorized as being at low or intermediate risk by $\mathrm{CHA}_{2} \mathrm{DS}_{2}-\mathrm{VASc}$ had significantly fewer thromboembolic events than their counterparts according to $\mathrm{CHADS}_{2}$ $(0.6 \%$ vs $3.3 \%)$.

Olesen et $\mathrm{al}^{24}$ similarly showed that in patients with a $\mathrm{CHADS}_{2}$ score of 0 , reclassification by $\mathrm{CHA}_{2} \mathrm{DS}_{2}$-VASc yielded a range of annual stroke rates from $0.84 \%$ with a score of 0 up to $3.2 \%$ with a score of 3 . 


\section{RISK-BASED ANTITHROMBOTIC THERAPY IN NONVALVULAR ATRIAL FIBRILLATION}

The 2014 atrial fibrillation guidelines ${ }^{1}$ state that the decision to give antithrombotic therapy for atrial fibrillation should be individualized, based on the absolute and relative risks of stroke and bleeding, and ought to take into consideration the patient's preferences. For patients with nonvalvular atrial fibrillation, selection of antithrombotic therapy should take into account the risk of thromboembolism determined by the $\mathrm{CHA}_{2} \mathrm{DS}_{2}$-VASc score and be irrespective of the pattern of atrial fibrillation (paroxysmal, persistent, or permanent).

Antithrombotic therapy is similarly recommended for patients with atrial flutter, according to the same risk profile used for atrial fibrillation.

Studies have consistently shown ${ }^{24-27}$ that the risk of ischemic stroke without anticoagulation exceeds the risk of intracranial bleeding with anticoagulation in nearly all patients except those at lowest risk of thromboembolism. The $\mathrm{CHA}_{2} \mathrm{DS}_{2}-\mathrm{VASc}$ score better identified those at truly low risk, in whom treatment may offer more risk than benefit. ${ }^{24-27}$

The HAS-BLED score ${ }^{28}$ assigns points as follows:

- Hypertension (systolic blood pressure > $160 \mathrm{~mm} \mathrm{Hg}$ ): 1 point

- Abnormal renal function (dialysis, renal transplantation, or serum creatinine $>2.6$ $\mathrm{mg} / \mathrm{mL}$ ) or liver function (cirrhosis, bilirubin more than two times the upper limit, or aminotransferase levels more than three times the upper limit): 1 or 2 points

- Stroke: 1 point

- Bleeding (prior major bleeding event or predisposition to bleeding): 1 point

- Labile international normalized ratio (INR) (supratherapeutic or time in therapeutic range $<60 \%)$ : 1 point

- Elderly (age > 65): 1 point

- Drugs (antiplatelet, nonsteroidal anti-inflammatory) or alcohol (more than eight drinks per week): 1 or 2 points

- Maximum total: 9 points.

HAS-BLED is a practical and validated approach for estimating bleeding risk and is mentioned in the guidelines, but it is not recommended for use in guiding decisions about antithrombotic therapy. Specifically, it should not be used to exclude patients, but rather to identify those at high risk (score 23 ) who may require closer observation and more attentive monitoring of the INR.

\section{ANTITHROMBOTIC THERAPY}

Antithrombotic agents available for use in the United States include antiplatelet drugs (eg, aspirin and clopidogrel) and anticoagulants (unfractionated heparin and low-molecularweight heparin, vitamin $\mathrm{K}$ antagonists such as warfarin, and direct thrombin and factor $\mathrm{Xa}$ inhibitors). Anticoagulation has been shown in randomized controlled trials to be superior to both placebo and antiplatelet agents used either alone or in combination. ${ }^{29}$ 
Aspirin has been downgraded-Aspirin has been compared with placebo in seven randomized controlled trials. Only the original SPAF study, in which aspirin $325 \mathrm{mg} / \mathrm{day}$ was used, found that it was beneficial. This result alone accounted for the $19 \%$ reduction in relative risk $(95 \%$ CI $1 \%-35 \%, P<.05)$ in a meta-analysis performed by Hart et al. ${ }^{29}$ Even when combined with clopidogrel $75 \mathrm{mg} /$ day, aspirin 75 to $100 \mathrm{mg} /$ day is still inferior to warfarin. ${ }^{5}$ While dual antiplatelet therapy resulted in a $28 \%$ relative reduction in thromboembolism (95\% CI 17\%-38\%, $P<.01$ ) compared with aspirin alone, major bleeding significantly increased by $57 \%$ (95\% CI 29\%-92\%, $P<.01)$.

Although aspirin may be beneficial, differences among patients may influence its efficacy. It may be more effective in preventing noncardioembolic stroke, particularly in diabetic and hypertensive patients. ${ }^{30,31}$ To date, aspirin has not been shown to be beneficial in low-risk populations.

The 2014 guidelines downgraded the recommendation for aspirin therapy. For patients at low risk and for some at intermediate risk, it is permissible to forgo therapy altogether, including aspirin. ${ }^{1}$

\section{ORAL ANTICOAGULANTS}

The rest of this paper reviews the oral anticoagulants that are approved for reducing the risk of thromboembolism in atrial fibrillation, focusing on each agent's mechanism of action, pharmacokinetics, clinical efficacy, and safety.

\section{WARFARIN, A VITAMIN K ANTAGONIST}

Warfarin inhibits synthesis of vitamin K-dependent clotting factors (ie, factors II, VII, IX, and $\mathrm{X}$ ) and proteins $\mathrm{C}$ and $\mathrm{S}$ by inhibiting the $\mathrm{C} 1$ subunit of vitamin $\mathrm{K}$ epoxide reductase, thereby interfering with production of vitamin $\mathrm{K}_{1}$ epoxide and consequent regeneration of vitamin $\mathrm{K}$.

Pharmacokinetics-Warfarin is nearly completely absorbed after oral administration. Its anticoagulant effect can be seen within 24 hours of administration, but its peak effect is typically apparent only after 72 hours. Elimination occurs predominantly through metabolism by cytochrome P450 enzymes, principally CYP2C9. Its effective half-life ranges from 20 to 60 hours, with a mean of 40 hours. ${ }^{32}$

Warfarin's effect, dosage, and bleeding risk are influenced by multiple factors, including vitamin K-containing foods such as green leafy vegetables, medications that either inhibit or induce hepatic cytochrome P450 enzymes, and polymorphisms in the VKORC1 and CYP2C9 genes. $^{32}$

Reversal-Warfarin's anticoagulant effect is reversed with vitamin K, but this reversal may not become apparent for 6 to 24 hours. In contrast, fresh-frozen plasma and prothrombin protein concentrate, which contain clotting factors, reverse warfarin immediately. Currently, a three-factor prothrombin protein concentrate (factors II, IX, and $\mathrm{X}$ ) and a four-factor concentrate (factors II, VII, IX, and X plus proteins $\mathrm{C}$ and S) are available in the United States. Although prothrombin protein concentrate works rapidly and 
has a lower volume of administration, available data do not indicate it is clinically superior to fresh-frozen plasma. ${ }^{33,34}$ The ongoing randomized PROTECT trial (NCT00618098), comparing fresh-frozen plasma and four-factor prothrombin protein concentrate for reversal of vitamin $\mathrm{K}$ antagonist therapy, may provide further insight.

Efficacy and safety-Randomized controlled trials in patients with nonvalvular atrial fibrillation have shown that warfarin (in doses adjusted to maintain an INR greater than 2) is highly efficacious in preventing systemic embolism, with a relative risk reduction of $61 \%$ (95\% CI $47 \%-71 \%, P<.05)$ compared with placebo. ${ }^{29,35}$ An INR of 2 to 3 is recommended for patients with nonvalvular atrial fibrillation, and those with atrial fibrillation and either a bioprosthetic valve or rheumatic heart disease. In contrast, an INR of 2.5 to 3.5 is recommended for patients with atrial fibrillation and mechanical valves in the aortic or mitral positions. 1,36

Stroke prevention with warfarin is most effective when the achieved mean time in the therapeutic range is at least $70 \%$. The risk of intracranial hemorrhage increases significantly at INRs higher than 3 . An INR of 2 to 3 offers maximum protection with minimal risk of bleeding. ${ }^{37,38}$ Systematic follow-up of patients through anticoagulation clinics produces better compliance and control and is encouraged.

\section{TARGET-SPECIFIC ORAL ANTICOAGULANTS}

Although effective, warfarin requires frequent monitoring and dosage adjustment, has a delayed onset and protracted offset, and interacts with commonly consumed vitamin $\mathrm{K}-$ containing foods and frequently used drugs. These drawbacks prompted evaluation of existing antiplatelet agents, in combination or in conjunction with lower adjusted or fixeddose warfarin. These regimens proved inferior, ${ }^{39-42}$ spurring interest in developing alternative oral anticoagulants.

TSOACs act by directly inhibiting thrombin (factor IIa) or by reducing thrombin production indirectly by inhibiting factor Xa. Three TSOACs are approved. Each was compared with adjusted-dose warfarin in randomized controlled trials.

\section{Dabigatran}

Dabigatran etexilate was the first TSOAC approved in the United States.

Pharmacokinetics-Dabigatran etexilate has a bioavailability of 3\% to $7 \%$ after oral administration. Its absorption is enhanced in an acidic gastric environment and is limited by P-glycoprotein-facilitated transport out of enterocytes. Dabigatran etexilate is hydrolyzed to its active metabolite dabigatran, which directly inhibits thrombin. Maximal plasma drug concentration and peak anticoagulant effect are achieved within 0.5 to 2 hours after administration.

Dabigatran is predominantly excreted by the kidneys, and has a half-life of 12 to 17 hours in patients with normal renal function. The half-life extends to 27 hours in those with moderately severe renal impairment (creati-nine clearance $15-30 \mathrm{~mL} / \mathrm{min}$ ). The recommended dose of $150 \mathrm{mg}$ twice daily should be reduced to $75 \mathrm{mg}$ twice daily in patients 
with a creatinine clearance of 15 to $30 \mathrm{~mL} / \mathrm{min}$. This drug is contraindicated in patients with a creatinine clearance less than $15 \mathrm{~mL} / \mathrm{min} .{ }^{43,44}$

Efficacy-The Randomized Evaluation of Long-term Anticoagulation Therapy (RELY) trial $^{45}$ randomly assigned 18,113 patients with nonvalvular atrial fibrillation at risk of thromboembolism (mean $\mathrm{CHADS}_{2}$ score 2.1) to receive either dabigatran (either $150 \mathrm{mg}$ twice daily or $110 \mathrm{mg}$ twice daily) or warfarin (adjusted to an INR of 2.0 to 3.0). Of note, the lower approved dose of dabigatran (75 mg twice daily) was not tested in RE-LY.

At 2 years, higher-dose dabigatran was significantly more effective than both warfarin (RR $0.65,95 \%$ CI $0.52-0.81, P<.05$ ) and lower-dose dabigatran (RR 0.73, 95\% CI 0.58-0.91, $P$ $<.05)$ in reducing the rate of systemic embolic events.

The risk of combined major bleeding events was no different with higher-dose dabigatran than with warfarin (RR 0.93, 95\% CI 0.81-1.07, $P<.05)$, but the rate of hemorrhagic stroke was significantly less with dabigatran than with warfarin (RR 0.26 , 95\% CI $0.14-0.49, P<$. $05)$. Higher rates of major gastrointestinal bleeding and dyspepsia occurred with dabigatran.

Concern about the safety of dabigatran was raised when post hoc evaluation of RE-LY found a higher incidence of myocardial infarction with dabigatran than with warfarin (RR $1.38,95 \%$ CI $1-1.91, P=.048) .{ }^{46}$ Corroborating data were reported by Uchino and Hernandez, ${ }^{47}$ comparing dabigatran with either warfarin or low-molecular-weight heparin. However, without directly comparing dabigatran and placebo, it is unclear whether the small increase in myocardial infarction reflects a direct effect of dabigatran or absence of a protective effect of warfarin or low-molecular-weight heparin.

\section{Rivaroxaban}

Rivaroxaban is a direct factor Xa inhibitor that blocks the amplified burst of thrombin production and in turn inhibits platelet aggregation and thrombus formation.

Pharmacokinetics-Rivaroxaban's oral bioavailability is $80 \%$ to $100 \%$ after a single 15 or 20-mg dose taken with food. Its maximal anticoagulant effect is achieved within 2 hours. Two-thirds of the active drug is metabolized by either CYP450-dependent (CYP3A4, 2J2) or CYP-independent mechanisms; the inactive drug is then excreted in the urine and feces. The remaining, active drug is removed by the kidneys using the P-glycoprotein transporter.

The half-life of rivaroxaban is 5 to 9 hours. The recommended dosage of $20 \mathrm{mg}$ daily should be reduced to $15 \mathrm{mg}$ daily if the creatinine clearance rate is 30 to $50 \mathrm{~mL} / \mathrm{min}$, or to $10 \mathrm{mg}$ if the creatinine clearance rate is 15 to $30 \mathrm{~mL} / \mathrm{min}$. Rivaroxaban is contraindicated in patients whose creatinine clearance rate is less than $15 \mathrm{~mL} / \mathrm{min}^{48-52}$

Efficacy and safety-In the Rivaroxaban Once Daily Oral Direct Factor Xa Inhibition Compared With Vitamin K Antagonism for Prevention of Stroke and Embolism Trial in Atrial Fibrillation (ROCKET-AF), ${ }^{53}$ 14,264 at-risk patients with nonvalvular atrial fibrillation (mean $\mathrm{CHADS}_{2}$ score 3.5) were randomly assigned to receive either rivaroxaban $20 \mathrm{mg}$ daily (or $15 \mathrm{mg}$ daily if their creatinine clearance was $30-49 \mathrm{~mL} / \mathrm{min}$; the lowest dose 
of rivaroxaban, $10 \mathrm{mg}$, was not studied in this trial) or warfarin (target INR 2.0-3.0).

Outcomes with rivaroxaban compared with warfarin:

- Systemic embolism: HR $0.79,95 \%$ CI $0.66-0.96, P<.01$, noninferiority

- Total bleeding: no difference

- Intracranial bleeding: HR 0.67, 95\% CI 0.47-0.93, $P=.02$

- Fatal bleeding: HR $0.50,95 \%$ CI $0.31-0.79, P=.003$

- Major gastrointestinal bleeding: $3.2 \%$ vs $2.2 \%, P<.001$.

\section{Apixaban}

Apixaban is also a direct factor Xa inhibitor.

Pharmacokinetics-Apixaban's oral bioavailability is 50\%, with maximal blood concentration achieved at 3 to 4 hours. One-quarter of the drug is metabolized via CYP3A4. The remaining active drug is excreted by the kidneys and biliary/intestinal system via the Pglycoprotein transporter. Apixaban's half-life is 9 to 14 hours.

The recommended dosage is $5 \mathrm{mg}$ twice daily, but it should be reduced to $2.5 \mathrm{mg}$ twice daily if at least two of the following characteristics are present: age 80 or older, weight $60 \mathrm{~kg}$ or less, and serum creatinine $1.5 \mathrm{mg} / \mathrm{dL}$ or more. ${ }^{54,55}$

Efficacy and safety-The Apixaban for Reduction in Stroke and Other Thromboembolic Events in Atrial Fibrillation (ARISTOTLE) trial ${ }^{56}$ enrolled 18,201 patients with nonvalvular atrial fibrillation (mean $\mathrm{CHADS}_{2}$ score 2.1) randomly assigned to receive either apixaban (5 $\mathrm{mg}$ twice daily with dosage reduction to $2.5 \mathrm{mg}$ twice daily as noted above) or warfarin (target INR 2.0-3.0).

Compared with warfarin, apixaban was associated with lower risk of:

- Systemic embolism (HR 0.79, 95\% CI 0.66-0.95, $P=.01$ )

- $\quad$ Major bleeding (HR 0.69, 95\% CI 0.60-0.80, $P<.001$ )

- Intracranial hemorrhage (HR 0.42, 95\% CI $0.30-0.58, P<.001$ )

- All-cause mortality (HR $0.8995 \%$ CI $0.80-0.99, P=.047$ ).

\section{Drug interactions with the novel oral anticoagulants}

TSOACs were developed with the intent to avoid many of the shortcomings of warfarin. Each has a broader therapeutic window and a rapid onset of action, enabling fixed dosing without need for serial monitoring. Compared with warfarin, they have significantly fewer dietary and drug interactions.

Nonetheless, drug interactions do exist and are important to recognize (TABLES 1-3). These primarily result from inhibition or induction of cytochrome P450 enzyme activity or P-glycoprotein transporter action, involved in metabolism and elimination of active drug. 


\section{Reversibility of the target-specific oral anticoagulants}

While the anticoagulant effects of warfarin can be reversed by vitamin K, fresh-frozen plasma, and prothrombin complex concentrate, TSOACs have no currently approved antidotes. Management of bleeding due to these agents was recently reviewed in this journal by Fawole et al. ${ }^{57}$

Several nonspecific hemostatic agents have been suggested, including recombinant factor VIIa or prothrombin complex concentrates. The anticoagulant effect of rivaroxaban has been shown to be reversed by prothrombin complex concentrate in vitro; clinical effect has not been demonstrated. ${ }^{58}$ PRT06445 (andexanet alfa), a recombinant protein antidote specific for factor Xa inhibitors, has entered clinical studies, with a phase 2 trial reporting high reversing capability for apixaban. ${ }^{59}$

Unlike rivaroxaban and apixaban, which are highly bound to plasma protein, dabigatran can be effectively removed with hemodialysis. Liesenfeld et al ${ }^{60}$ showed that longer dialysis duration was the most relevant variable for reducing dabigatran plasma levels. Current clinical experience is limited, and standard recommendations and formal guidance are lacking.

\section{Switching oral anticoagulants}

Suggested approaches for switching between anticoagulants are listed in TABLE $4 .{ }^{61}$

\section{CHOOSING ANTITHROMBOTIC THERAPY}

\section{In valvular atrial fibrillation: warfarin}

Anticoagulation with warfarin is advised for valvular atrial fibrillation. Patients with bioprosthetic heart valves or rheumatic valvular disease were not evaluated in randomized controlled trials of TSOACs. Dabigatran in particular is contraindicated in patients with mechanical heart valves, as the Randomized, Phase II Study to Evaluate the Safety and Pharmacokinetics of Oral Dabigatran Etexilate in Patients After Heart Valve Replacement (RE-ALIGN) ${ }^{62}$ found higher rates of stroke, valve-related thrombosis, and myocardial infarction in patients receiving dabigatran.

\section{In nonvalvular atrial fibrillation}

According to the 2014 guidelines, ${ }^{1}$ oral anticoagulation is preferred in all patients with nonvalvular atrial fibrillation but those at lowest risk $\left(\mathrm{CHA}_{2} \mathrm{DS}_{2}-\mathrm{VASc}=0\right)$.

Experience with TSOACs is lacking in patients with end-stage kidney disease (creatinine clearance $<15 \mathrm{~mL} / \mathrm{min}$ ), and warfarin is advised in this group.

TSOACs are recommended in patients with nonvalvular atrial fibrillation in whom therapeutic INR levels cannot be maintained with warfarin. For most patients with nonvalvular atrial fibrillation, TSOACs are an option equivalent to warfarin. Anticoagulant choice is largely driven by dosing convenience, outof-pocket cost for treatment with a TSOAC, and ready availability of antidotes for warfarin in case of bleeding (TABLES 5 AND $6)$. 
In patients with nonvalvular atrial fibrillation, TSOACs are as effective as warfarin in preventing systemic thromboembolism, and some of them have been shown to be superior in terms of lower rates of ischemic stroke (dabigatran), systemic embolism (apixaban), and mortality (apixaban; trend for dabigatran). All TSOACs demonstrate modestly favorable bleeding risk profiles compared with warfarin, with lower risk of intracranial hemorrhage. Potential differences in efficacy and safety among TSOACs are unknown since there have been no randomized direct comparisons between them. A summary of landmark trial results and assessment of the advantages and disadvantages of each are listed in TABLE 7.

Two groups of patients with nonvalvular atrial fibrillation warrant special consideration:

Patients with hypertrophic cardiomyopathy-There are no randomized controlled trials of anticoagulation therapy in patients with hypertrophic cardiomyopathy; however, because of their high risk of thromboembolism, anticoagulation is indicated irrespective of the $\mathrm{CHA}_{2} \mathrm{DS}_{2}$-VASc score. TSOACs are an option as an alternative to warfarin.

\section{Patients with coronary artery disease and an indication for antiplatelet}

therapy-In this group the decision for concurrent anticoagulation is guided by the $\mathrm{CHA}_{2} \mathrm{DS}_{2}$-VASc score. For patients who have intracoronary stents, dual antiplatelet therapy is the standard of care for reducing risk of cardiovascular events after stent implantation. ${ }^{63}$ When triple therapy (ie, two antiplatelet drugs and an anticoagulant) is indicated, such as after intracoronary stent placement, the guidelines suggest trying to minimize the duration of triple therapy. For instance, a bare-metal stent may be preferred. Alternatively, after coronary revascularization, it may be reasonable to use clopidogrel $75 \mathrm{mg}$ daily with an oral anticoagulant and to omit aspirin.

\section{Interrupting and bridging anticoagulation}

Patients with atrial fibrillation often require suspension of anticoagulation, most commonly before an elective invasive procedure. The duration of interruption, timing of resumption, and need for bridging anticoagulation are guided by clinical judgment, which considers risk of thromboembolism and severity of procedure-related bleeding risk.

In general, if therapy needs to be interrupted, it should be restarted as soon as possible. Short-term interruption does not seem to be associated with clinically significant risk of thromboembolic events, whereas postoperative heparin bridging therapy increases the risk of hematoma with implantation of a cardiac electronic device. ${ }^{64,65}$

To date, evidence is lacking to advise upon periprocedure bridging anticoagulation. The Bridging Anticoagulation in Patients Who Require Temporary Interruption of Warfarin Therapy for an Elective Invasive Procedure or Surgery (BRIDGE) study (NCT00786474)— enrolling chronically anticoagulated patients undergoing an invasive procedure to randomly receive placebo or bridging low-molecular-weight heparin—may provide guidance.

Currently, it is common practice in low-risk patients undergoing an invasive procedure with significant bleeding risk to interrupt anticoagulation for up to 1 week without bridging.

Warfarin is typically held 3 to 5 days, while TSOACs are held for 24 hours if renal function 
is preserved or up to 2 to 3 days if renal function is severely impaired (creatinine clearance $15-30 \mathrm{~mL} / \mathrm{min}$ ). If complete hemostasis is necessary, it could be confirmed by a normalized INR (for warfarin), activated partial thromboplastin time (dabigatran), or prothrombin time (apixaban or rivaroxaban).

For patients at high risk (valvular atrial fibrillation or $\mathrm{CHA}_{2} \mathrm{DS}_{2}-\mathrm{VASc} \geq 2$ ), bridging with unfractionated heparin or low-molecular-weight heparin during periods of subtherapeutic anticoagulation is common. Alternatively, it is becoming increasingly common to perform cardiac electronic device implantation, catheter ablation, and coronary angiography and intervention without interrupting anticoagulation. ${ }^{66-72}$

Recently, concern has been raised over a possible increase in thromboembolism upon discontinuation of rivaroxaban and apixaban. ROCKET-AF reported a spike in thrombotic events in the rivaroxaban-treated group at the end of the trial (HR 1.50, 95\% CI 1.05-2.15, $P$ $=.026$ ). This raised concern for a possible "rebound" effect upon drug cessation. Yet a post hoc analysis of ROCKET-AF demonstrated that events clustered in the rivaroxaban-treated cohort who completed the study and were transitioning to open-label warfarin, and this alone accounted for the rise in stroke occurrence. In contrast, there was no increase in the cohort of patients treated with rivaroxaban who either temporarily interrupted or permanently discontinued the drug. ${ }^{73}$ The authors concluded that increased stroke was the consequence of transiently interrupted anticoagulation, rather than a rebound prothrombotic effect. Similar results were reported in ARISTOTLE.

Another possibility is that, during the transition to warfarin therapy, transient hypercoagulability could be a function of warfarin. Azoulay et al ${ }^{74}$ observed in a large cohort that warfarin was associated with a $71 \%$ increased risk of stroke in the first 30 days after initiation, compared with decreased risk thereafter. Nevertheless, there is now a blackbox warning recommendation for all three TSOACs that if discontinuation is required for a reason other than pathological bleeding, bridging with another anticoagulant should at least be considered.

The perioperative management of the TSOACs was recently reviewed in this journal by Anderson et al. ${ }^{75}$

\section{WEIGHING THE RISKS OF STROKE AND BLEEDING}

Stroke is the most feared complication in patients with atrial fibrillation. Risk reduction is an important goal in management, yet decisions for individuals must take into account both stroke and bleeding risks related to antithrombotic therapy.

The 2014 guidelines ${ }^{1}$ differ from past versions. First, they endorse the use of $\mathrm{CHA}_{2} \mathrm{DS}_{2^{-}}$ VASc for categorizing stroke risk in patients with nonvalvular atrial fibrillation. This in turn guides antithrombotic therapy. This scheme effectively identifies patients at very low risk of stroke (men with a score of 0 , women with a score of 0 or 1 ), in whom it is reasonable to omit antithrombotic therapy. For all patients with valvular heart disease or hypertrophic cardiomyopathy, unless bleeding risk is prohibitive, anticoagulation is recommended 
irrespective of the $\mathrm{CHA}_{2} \mathrm{DS}_{2}$-VASc score. Second, they incorporate the TSOACs, which offer convenience and improved safety in select patients.

While the guidelines mention the potential relevance of subclinical atrial tachyarrhythmias as they pertain to stroke risk, there is no specific recommendation as to their management. We do take into consideration the finding of atrial high-rate events ( $\geq 180 \mathrm{bpm}, \geq 6$ minutes in duration) diagnostically confirmed by cardiac implantable electronic devices or telemetric monitoring, particularly in patients with a clinical profile of high stroke risk. In addition, atriopathy with increased left atrial size and renal insufficiency, as discussed in this review, appear to correlate with greater risk of thromboembolism, yet neither is a component of the stroke risk scheme endorsed by the guidelines.

Other risk factors, some unknown to us, undoubtedly exist. Again, our empiric judgment is to at least consider these nontraditional risk factors while guided primarily by the $\mathrm{CHA}_{2} \mathrm{DS}_{2}$-VASc score when assessing stroke risk in patients with atrial fibrillation.

The goal in managing patients with atrial fibrillation is to balance thromboembolic risk reduction with the risk of bleeding associated with antithrombotic therapy.

Subclinical atrial fibrillation may be an important cause of stroke

Compared with $\mathrm{CHADS}_{2}, \mathrm{CHA}_{2} \mathrm{DS}_{2}$-VASc has superior negative predictive power

HAS-BLED should not be used to exclude patients from anticoagulation therapy

An INR of 2 to 3 offers maximum protection with minimal risk of bleeding

Post hoc analysis found more myocardial infarctions with dabigatran than with warfarin

Target-specific oral anticoagulants have no approved antidotes, but several have been suggested

In general, if therapy needs to be interrupted, it should be restarted as soon as possible

In deciding whether to start anticoagulation, weigh the risk of both stroke and bleeding

\section{REFERENCES}

1. January CT, Wann LS, Alpert JS, et al. 2014 AHA/ACC/HRS Guideline for the Management of Patients With Atrial Fibrillation: A Report of the American College of Cardiology/American Heart Association Task Force on Practice Guidelines and the Heart Rhythm Society. Circulation. 2014; 130:2071-2104. [PubMed: 24682348]

2. Kannel WB, Abbott RD, Savage DD, McNamara PM. Epidemiologic features of chronic atrial fibrillation: the Framingham study. N Engl J Med. 1982; 306:1018-1022. [PubMed: 7062992]

3. Lloyd-Jones DM, Wang TJ, Leip EP, et al. Lifetime risk for development of atrial fibrillation: the Framingham Heart Study. Circulation. 2004; 110:1042-1046. [PubMed: 15313941]

4. Wolf PA, Abbott RD, Kannel WB. Atrial fibrillation as an independent risk factor for stroke: the Framingham Study. Stroke. 1991; 22:983-988. [PubMed: 1866765] 
5. Hart RG, Pearce LA, Rothbart RM, McAnulty JH, Asinger RW, Halperin JL. Stroke with intermittent atrial fibrillation: incidence and predictors during aspirin therapy. Stroke Prevention in Atrial Fibrillation Investigators. J Am Coll Cardiol. 2000; 35:183-187. [PubMed: 10636278]

6. Hohnloser SH, Pajitnev D, Pogue J, et al. ACTIVE W Investigators. Incidence of stroke in paroxysmal versus sustained atrial fibrillation in patients taking oral anticoagulation or combined antiplatelet therapy: an ACTIVE W Substudy. J Am Coll Cardiol. 2007; 50:2156-2161. [PubMed: 18036454]

7. Healey JS, Connolly SJ, Gold MR, et al. ASSERT Investigators. Subclinical atrial fibrillation and the risk of stroke. N Engl J Med. 2012; 366:120-129. [PubMed: 22236222]

8. Glotzer TV, Hellkamp AS, Zimmerman J, et al. MOST Investigators. Atrial high rate episodes detected by pacemaker diagnostics predict death and stroke: report of the Atrial Diagnostics Ancillary Study of the MOde Selection Trial (MOST). Circulation. 2003; 107:1614-1619. [PubMed: 12668495]

9. Glotzer TV, Daoud EG, Wyse DG, et al. The relationship between daily atrial tachyarrhythmia burden from implantable device diagnostics and stroke risk: the TRENDS study. Circ Arrhythm Electrophysiol. 2009; 2:474-480. [PubMed: 19843914]

10. Atrial Fibrillation Investigators. Risk factors for stroke and efficacy of antithrombotic therapy in atrial fibrillation. Analysis of pooled data from five randomized controlled trials. Arch Intern Med. 1994; 154:1449-1457. [PubMed: 8018000]

11. Maron BJ, Olivotto I, Bellone P, et al. Clinical profile of stroke in 900 patients with hypertrophic cardiomyopathy. J Am Coll Cardiol. 2002; 39:301-307. [PubMed: 11788223]

12. Olivotto I, Cecchi F, Casey SA, Dolara A, Traverse JH, Maron BJ. Impact of atrial fibrillation on the clinical course of hypertrophic cardiomyopathy. Circulation. 2001; 104:2517-2524. [PubMed: 11714644]

13. Go AS, Fang MC, Udaltsova N, et al. ATRIA Study Investigators. Impact of proteinuria and glomerular filtration rate on risk of thromboembolism in atrial fibrillation: the anticoagulation and risk factors in atrial fibrillation (ATRIA) study. Circulation. 2009; 119:1363-1369. [PubMed: 19255343]

14. Hart RG, Pearce LA, Asinger RW, Herzog CA. Warfarin in atrial fibrillation patients with moderate chronic kidney disease. Clin J Am Soc Nephrol. 2011; 6:2599-2604. [PubMed: 21903982]

15. Vázquez E, Sánchez-Perales C, Borrego F, et al. Influence of atrial fibrillation on the morbidomortality of patients on hemodialysis. Am Heart J. 2000; 140:886-890. [PubMed: 11099992]

16. The Stroke Prevention in Atrial Fibrillation Investigators Committee on Echocardiography. Transesophageal echocardiographic correlates of thromboembolism in high-risk patients with nonvalvular atrial fibrillation. Ann Intern Med. 1998; 128:639-647. [PubMed: 9537937]

17. The Stroke Prevention in Atrial Fibrillation Investigators. Predictors of thromboembolism in atrial fibrillation: II. Echocardiographic features of patients at risk. Ann Intern Med. 1992; 116:6-12. [PubMed: 1727097]

18. Osranek M, Bursi F, Bailey KR, et al. Left atrial volume predicts cardiovascular events in patients originally diagnosed with lone atrial fibrillation: three-decade follow-up. Eur Heart J. 2005; 26:2556-2561. [PubMed: 16141257]

19. Gage BF, Waterman AD, Shannon W, Boechler M, Rich MW, Radford MJ. Validation of clinical classification schemes for predicting stroke: results from the National Registry of Atrial Fibrillation. JAMA. 2001; 285:2864-2870. [PubMed: 11401607]

20. van Walraven C, Hart RG, Wells GA, et al. A clinical prediction rule to identify patients with atrial fibrillation and a low risk for stroke while taking aspirin. Arch Intern Med. 2003; 163:936-943. [PubMed: 12719203]

21. Camm AJ, Lip GY, De Caterina R, et al. ESC Committee for Practice Guidelines (CPG). 2012 focused update of the ESC Guidelines for the management of atrial fibrillation: an update of the 2010 ESC Guidelines for the management of atrial fibrillation. Developed with the special contribution of the European Heart Rhythm Association. Eur Heart J. 2012; 33:2719-2747. [PubMed: 22922413] 
22. Lip GY, Frison L, Halperin JL, Lane DA. Identifying patients at high risk for stroke despite anticoagulation: a comparison of contemporary stroke risk stratification schemes in an anticoagulated atrial fibrillation cohort. Stroke. 2010; 41:2731-2738. [PubMed: 20966417]

23. Lip GY, Nieuwlaat R, Pisters R, Lane DA, Crijns HJ. Refining clinical risk stratification for predicting stroke and thromboembolism in atrial fibrillation using a novel risk factor-based approach: the Euro Heart Survey on Atrial Fibrillation. Chest. 2010; 137:263-272. [PubMed: 19762550]

24. Olesen JB, Torp-Pedersen C, Hansen ML, Lip GY. The value of the CHA2DS2-VASc score for refining stroke risk stratification in patients with atrial fibrillation with a CHADS2 score 0-1: a nationwide cohort study. Thromb Haemost. 2012; 107:1172-1179. [PubMed: 22473219]

25. Singer DE, Chang Y, Fang MC, et al. The net clinical benefit of warfarin anticoagulation in atrial fibrillation. Ann Intern Med. 2009; 151:297-305. [PubMed: 19721017]

26. Olesen JB, Lip GY, Lindhardsen J, et al. Risks of thromboembolism and bleeding with thromboprophylaxis in patients with atrial fibrillation: a net clinical benefit analysis using a 'real world' nationwide cohort study. Thromb Haemost. 2011; 106:739-749. [PubMed: 21789337]

27. Friberg L, Rosenqvist M, Lip GY. Net clinical benefit of warfarin in patients with atrial fibrillation: a report from the Swedish atrial fibrillation cohort study. Circulation. 2012; 125:22982307. [PubMed: 22514252]

28. Pisters R, Lane DA, Nieuwlaat R, de Vos CB, Crijns HJ, Lip GY. A novel user-friendly score (HAS-BLED) to assess 1-year risk of major bleeding in patients with atrial fibrillation: the Euro Heart Survey. Chest. 2010; 138:1093-1100. [PubMed: 20299623]

29. Hart RG, Pearce LA, Aguilar MI. Meta-analysis: antithrombotic therapy to prevent stroke in patients who have nonvalvular atrial fibrillation. Ann Intern Med. 2007; 146:857-867. [PubMed: 17577005]

30. The Atrial Fibrillation Investigators. The efficacy of aspirin in patients with atrial fibrillation. Analysis of pooled data from 3 randomized trials. Arch Intern Med. 1997; 157:1237-1240. [PubMed: 9183235]

31. Miller VT, Rothrock JF, Pearce LA, Feinberg WM, Hart RG, Anderson DC. Ischemic stroke in patients with atrial fibrillation: effect of aspirin according to stroke mechanism. Stroke Prevention in Atrial Fibrillation Investigators. Neurology. 1993; 43:32-36. [PubMed: 8423907]

32. Holbrook AM, Pereira JA, Labiris R, et al. Systematic overview of warfarin and its drug and food interactions. Arch Intern Med. 2005; 165:1095-1106. [PubMed: 15911722]

33. Boulis NM, Bobek MP, Schmaier A, Hoff JT. Use of factor IX complex in warfarin-related intracranial hemorrhage. Neurosurgery. 1999; 45:1113-1119. [PubMed: 10549927]

34. Huttner HB, Schellinger PD, Hartmann M, et al. Hematoma growth and outcome in treated neurocritical care patients with intracerebral hemorrhage related to oral anticoagulant therapy: comparison of acute treatment strategies using vitamin $\mathrm{K}$, fresh frozen plasma, and prothrombin complex concentrates. Stroke. 2006; 37:1465-1470. [PubMed: 16675739]

35. Hart RG, Benavente O, McBride R, Pearce LA. Antithrombotic therapy to prevent stroke in patients with atrial fibrillation: a meta-analysis. Ann Intern Med. 1999; 131:492-501. [PubMed: 10507957]

36. Ansell J, Hirsh J, Hylek E, Jacobson A, Crowther M, Palareti G, American College of Chest Physicians. Pharmacology and management of the vitamin K antagonists: American College of Chest Physicians Evidence-Based Clinical Practice Guidelines (8th Edition). Chest. 2008; 133(suppl 6):160S-198S. [PubMed: 18574265]

37. Gallagher AM, Setakis E, Plumb JM, Clemens A, van Staa TP. Risks of stroke and mortality associated with suboptimal anticoagulation in atrial fibrillation patients. Thromb Haemost. 2011; 106:968-977. [PubMed: 21901239]

38. Odén A, Fahlén M, Hart RG. Optimal INR for prevention of stroke and death in atrial fibrillation: a critical appraisal. Thromb Res. 2006; 117:493-499. [PubMed: 16517250]

39. ACTIVE Writing Group of the ACTIVE Investigators. Connolly S, Pogue J, Hart R, et al. Clopidogrel plus aspirin versus oral anticoagulation for atrial fibrillation in the Atrial fibrillation Clopidogrel Trial with Irbesartan for prevention of Vascular Events (ACTIVE W): a randomised controlled trial. Lancet. 2006; 367:1903-1912. [PubMed: 16765759] 
40. ACTIVE Investigators. Connolly SJ, Pogue J, Hart RG, et al. Effect of clopidogrel added to aspirin in patients with atrial fibrillation. N Engl J Med. 2009; 360:2066-2078. [PubMed: 19336502]

41. Adjusted-dose warfarin versus low-intensity, fixed-dose warfarin plus aspirin for high-risk patients with atrial fibrillation: Stroke Prevention in Atrial Fibrillation III randomised clinical trial. Lancet. 1996; 348:633-638. [PubMed: 8782752]

42. Gulløv AL, Koefoed BG, Petersen P, et al. Fixed minidose warfarin and aspirin alone and in combination vs adjusted-dose warfarin for stroke prevention in atrial fibrillation: Second Copenhagen Atrial Fibrillation, Aspirin, and Anticoagulation Study. Arch Intern Med. 1998; 158:1513-1521. [PubMed: 9679792]

43. Blech S, Ebner T, Ludwig-Schwellinger E, Stangier J, Roth W. The metabolism and disposition of the oral direct thrombin inhibitor, dabigatran, in humans. Drug Metab Dispos. 2008; 36:386-399. [PubMed: 18006647]

44. Stangier J, Rathgen K, Stähle H, Gansser D, Roth W. The pharmacokinetics, pharmacodynamics and tolerability of dabigatran etexilate, a new oral direct thrombin inhibitor, in healthy male subjects. Br J Clin Pharmacol. 2007; 64:292-303. [PubMed: 17506785]

45. Connolly SJ, Ezekowitz MD, Yusuf S, et al. RE-LY Steering Committee and Investigators. Dabigatran versus warfarin in patients with atrial fibrillation. N Engl J Med. 2009; 361:11391151. [PubMed: 19717844]

46. Hohnloser SH, Oldgren J, Yang S, et al. Myocardial ischemic events in patients with atrial fibrillation treated with dabigatran or warfarin in the RE-LY (Randomized Evaluation of LongTerm Anticoagulation Therapy) trial. Circulation. 2012; 125:669-676. [PubMed: 22215856]

47. Uchino K, Hernandez AV. Dabigatran association with higher risk of acute coronary events: metaanalysis of noninferiority randomized controlled trials. Arch Intern Med. 2012; 172:397-402. [PubMed: 22231617]

48. Kubitza D, Becka M, Voith B, Zuehlsdorf M, Wensing G. Safety, pharmacodynamics, and pharmacokinetics of single doses of BAY 59-7939, an oral, direct factor Xa inhibitor. Clin Pharmacol Ther. 2005; 78:412-421. [PubMed: 16198660]

49. Kubitza D, Becka M, Wensing G, Voith B, Zuehlsdorf M. Safety, pharmacodynamics, and pharmacokinetics of BAY 59-7939—an oral, direct Factor Xa inhibitor — after multiple dosing in healthy male subjects. Eur J Clin Pharmacol. 2005; 61:873-880. [PubMed: 16328318]

50. Kubitza D, Becka M, Roth A, Mueck W. Dose-escalation study of the pharmacokinetics and pharmacodynamics of rivaroxaban in healthy elderly subjects. Curr Med Res Opin. 2008; 24:2757-2765. [PubMed: 18715524]

51. Weinz C, Schwarz T, Kubitza D, Mueck W, Lang D. Metabolism and excretion of rivaroxaban, an oral, direct factor Xa inhibitor, in rats, dogs, and humans. Drug Metab Dispos. 2009; 37:10561064. [PubMed: 19196845]

52. Perzborn E, Roehrig S, Straub A, Kubitza D, Misselwitz F. The discovery and development of rivaroxaban, an oral, direct factor Xa inhibitor. Nat Rev Drug Discov. 2011; 10:61-75. [PubMed: 21164526]

53. Patel MR, Mahaffey KW, Garg J, et al. ROCKET AF Investigators. Rivaroxaban versus warfarin in nonvalvular atrial fibrillation. N Engl J Med. 2011; 365:883-891. [PubMed: 21830957]

54. Wong PC, Pinto DJ, Zhang D. Preclinical discovery of apixaban, a direct and orally bioavailable factor Xa inhibitor. J Thromb Thrombolysis. 2011; 31:478-492. [PubMed: 21318583]

55. Carreiro J, Ansell J. Apixaban, an oral direct Factor Xa inhibitor: awaiting the verdict. Expert Opin Investig Drugs. 2008; 17:1937-1945.

56. Granger CB, Alexander JH, McMurray JJ, et al. ARISTOTLE Committees and Investigators. Apixaban versus warfarin in patients with atrial fibrillation. N Engl J Med. 2011; 365:981-992. [PubMed: 21870978]

57. Fawole A, Daw HA, Crowther MA. Practical management of bleeding due to the anticoagulants dabigatran, rivaroxaban, and apixaban. Cleve Clin J Med. 2013; 80:443-451. [PubMed: 23821689]

58. Eerenberg ES, Kamphuisen PW, Sijpkens MK, Meijers JC, Buller HR, Levi M. Reversal of rivaroxaban and dabigatran by prothrombin complex concentrate: a randomized, placebo- 
controlled, crossover study in healthy subjects. Circulation. 2011; 124:1573-1579. [PubMed: 21900088]

59. Lu G, DeGuzman FR, Hollenbach SJ, et al. A specific antidote for reversal of anticoagulation by direct and indirect inhibitors of coagulation factor Xa. Nat Med. 2013; 19:446-451. [PubMed: 23455714]

60. Liesenfeld KH, Staab A, Härtter S, Formella S, Clemens A, Lehr T. Pharmacometric characterization of dabigatran hemodialysis. Clin Pharmacokinet. 2013; 52:453-462. [PubMed: 23529813]

61. MPR. Monthly Prescribing Reference. [Accessed December 11, 2014] Anticoagulant dosing conversions. Aug 18. 2014 www.empr.com/anticoagulant-dosing-conversions/article/194271/

62. Eikelboom JW, Connolly SJ, Brueckmann M, et al. RE-ALIGN Investigators. Dabigatran versus warfarin in patients with mechanical heart valves. N Engl J Med. 2013; 369:1206-1214. [PubMed: 23991661]

63. Brilakis ES, Patel VG, Banerjee S. Medical management after coronary stent implantation: a review. JAMA. 2013; 310:189-198. [PubMed: 23839753]

64. Tischenko A, Gula LJ, Yee R, Klein GJ, Skanes AC, Krahn AD. Implantation of cardiac rhythm devices without interruption of oral anticoagulation compared with perioperative bridging with low-molecular weight heparin. Am Heart J. 2009; 158:252-256. [PubMed: 19619702]

65. Robinson M, Healey JS, Eikelboom J, et al. Postoperative low-molecular-weight heparin bridging is associated with an increase in wound hematoma following surgery for pacemakers and implantable defibrillators. Pacing Clin Electrophysiol. 2009; 32:378-382. [PubMed: 19272069]

66. Birnie DH, Healey JS, Wells GA, et al. BRUISE CONTROL Investigators. Pacemaker or defibrillator surgery without interruption of anticoagulation. N Engl J Med. 2013; 368:2084-2093. [PubMed: 23659733]

67. Ahmed I, Gertner E, Nelson WB, et al. Continuing warfarin therapy is superior to interrupting warfarin with or without bridging anticoagulation therapy in patients undergoing pacemaker and defibrillator implantation. Heart Rhythm. 2010; 7:745-749. [PubMed: 20176137]

68. Cheng A, Nazarian S, Brinker JA, et al. Continuation of warfarin during pacemaker or implantable cardioverter-defibrillator implantation: a randomized clinical trial. Heart Rhythm. 2011; 8:536540. [PubMed: 21147261]

69. Jamula E, Lloyd NS, Schwalm JD, Airaksinen KE, Douketis JD. Safety of uninterrupted anticoagulation in patients requiring elective coronary angiography with or without percutaneous coronary intervention: a systematic review and metaanalysis. Chest. 2010; 138:840-847. [PubMed: 20435662]

70. Jamula E, Douketis JD, Schulman S. Perioperative anticoagulation in patients having implantation of a cardiac pacemaker or defibrillator: a systematic review and practical management guide. $\mathbf{J}$ Thromb Haemost. 2008; 6:1615-1621. [PubMed: 18638011]

71. Korantzopoulos P, Letsas KP, Liu T, Fragakis N, Efremidis M, Goudevenos JA. Anticoagulation and antiplatelet therapy in implantation of electrophysiological devices. Europace. 2011; 13:16691680. [PubMed: 21788280]

72. Di Biase L, Burkhardt JD, Mohanty P, et al. Periprocedural stroke and management of major bleeding complications in patients undergoing catheter ablation of atrial fibrillation: the impact of periprocedural therapeutic international normalized ratio. Circulation. 2010; 121:2550-2556. [PubMed: 20516376]

73. Patel MR, Hellkamp AS, Lokhnygina Y, et al. Outcomes of discontinuing rivaroxaban compared with warfarin in patients with nonvalvular atrial fibrillation: analysis from the ROCKET AF trial (Rivaroxaban Once-Daily, Oral, Direct Factor Xa Inhibition Compared With Vitamin K Antagonism for Prevention of Stroke and Embolism Trial in Atrial Fibrillation). J Am Coll Cardiol. 2013; 61:651-658. [PubMed: 23391196]

74. Azoulay L, Dell'aniello S, Simon TA, Renoux C, Suissa S. Initiation of warfarin in patients with atrial fibrillation: early effects on ischaemic strokes. Eur Heart J. Dec 18.2013 [Epub ahead of print].

75. Anderson M, Hassell KL, Trujillo TC, Wolfe B. When patients on target-specific oral anticoagulants need surgery. Cleve Clin J Med. 2014; 81:629-639. [PubMed: 25274657] 


\section{KEY POINTS}

Valvular atrial fibrillation poses a high risk of systemic embolization, particularly stroke, and nearly all patients who have valvular atrial fibrillation need anticoagulation therapy with warfarin.

Nonvalvular atrial fibrillation poses a somewhat lower risk. The new guidelines propose a new risk-classification scheme, called $\mathrm{CHA}_{2} \mathrm{DS}_{2}$-VASc; patients at very low risk of stroke may be able to forgo anticoagulation.

The new guidelines downplay the role of aspirin, although it is still an option in some situations.

Several novel oral anticoagulants have been approved in the past few years for thromboprophylaxis in patients with nonvalvular atrial fibrillation. 


\section{Studies discussed in this paper}

ACTIVE W-Atrial Fibrillation Clopidogrel Trial With Irbesartan for Prevention of Vascular Events ${ }^{6}$

ARISTOTLE- Apixaban for Reduction in Stroke and Other Thromboembolic Events in Atrial Fibrillation ${ }^{56}$

BRIDGE-Bridging Anticoagulation in Patients Who Require Temporary Interruption of Warfarin Therapy for an Elective Invasive Procedure or Surgery

RE-ALIGN—Randomized, Phase II Study to Evaluate the Safety and Pharmacokinetics of Oral Dabigatran Etexilate in Patients After Heart Valve Replacement ${ }^{62}$

RE-LY-Randomized Evaluation of Long-Term Anticoagulation Therapy 45,46

ROCKET-AF-Rivaroxaban Once Daily Oral Direct Factor Xa Inhibition Compared With Vitamin K Antagonism for Prevention of Stroke and Embolism Trial in Atrial Fibrillation $^{53}$

SPAF-Stroke Prevention in Atrial Fibrillation ${ }^{5,16,17,29}$ 


\section{TABLE 1}

Drug interactions with dabigatran

\begin{tabular}{llll}
\hline Mechanism of interaction & Specific agents & Effect & Recommendation \\
\hline P-glycoprotein-1 inducers & Rifampin & $\begin{array}{l}\text { Decrease } \\
\text { dabigatran's } \\
\text { action }\end{array}$ & Consider alternative anticoagulant \\
$\begin{array}{l}\text { P-glycoprotein-1 inhibitors } \\
\text { (creatinine clearance 30-50 } \\
\text { mL/min) }\end{array}$ & Ketoconazole, dronedarone & $\begin{array}{l}\text { Increase } \\
\text { dabigatran's } \\
\text { action }\end{array}$ & $\begin{array}{l}\text { Reduce dose to 75 mg twice daily or } \\
\text { consider alternative anticoagulant }\end{array}$ \\
$\begin{array}{l}\text { P-glycoprotein-1 inhibitors } \\
\text { (creatinine clearance 15-30 } \\
\text { mL/min) }\end{array}$ & $\begin{array}{l}\text { Ketoconazole, dronedarone, } \\
\text { amiodarone, verapamil, } \\
\text { diltiazem, clarithromycin }\end{array}$ & $\begin{array}{l}\text { Increase } \\
\text { dabigatran's } \\
\text { action }\end{array}$ & Consider alternative anticoagulant \\
\hline
\end{tabular}


TABLE 2

Drug interactions with rivaroxaban

\begin{tabular}{llll}
\hline Mechanism of interaction & Specific agents & Effect & Recommendation \\
\hline $\begin{array}{l}\text { Strong dual cytochrome P450 } \\
\text { 3A4 (CYP3A) and }\end{array}$ & $\begin{array}{l}\text { Rifampin, carbamazepine, } \\
\text { phenytoin, St. John's wort }\end{array}$ & $\begin{array}{l}\text { Decrease } \\
\text { rivaroxaban's } \\
\text { action }\end{array}$ & Consider alternative anticoagulant \\
$\begin{array}{l}\text { Strong dual CYP3A4 and } \\
\text { P-glycoprotein-1 inhibitors }\end{array}$ & $\begin{array}{l}\text { Ketoconazole, itraconazole, hu- } \\
\text { man immunodeficiency virus (HIV) } \\
\text { protease inhibitors, conivaptan }\end{array}$ & $\begin{array}{l}\text { Increase } \\
\text { rivaroxaban's } \\
\text { action }\end{array}$ & Consider alternative anticoagulant \\
$\begin{array}{l}\text { Weak or moderate dual } \\
\begin{array}{l}\text { CYP3A4 and P-glycoprotein-1 } \\
\text { inhibitors and creatinine clear- } \\
\text { ance 15-50 mL/min }\end{array}\end{array}$ & $\begin{array}{l}\text { Amiodarone, verapamil, } \\
\text { diltiazem, erythromycin, }\end{array}$ & $\begin{array}{l}\text { Increase } \\
\text { rivaroxaban's } \\
\text { action }\end{array}$ & Consider alternative anticoagulant \\
\hline
\end{tabular}


TABLE 3

Drug interactions with apixaban

\begin{tabular}{llll}
\hline Mechanism of interaction & Specific agents & Effect & Recommendation \\
\hline $\begin{array}{l}\text { Strong dual cytochrome P450 } \\
\text { 3A4 (CYP3A4) and }\end{array}$ & $\begin{array}{l}\text { Rifampin, carbamazepine, } \\
\text { phenytoin, St. John's wort }\end{array}$ & $\begin{array}{l}\text { Decrease } \\
\text { apixaban's } \\
\text { action }\end{array}$ & Consider alternative anticoagulant \\
$\begin{array}{l}\text { Strong dual CYP3A4 and } \\
\text { P-glycoprotein-1 inhibitors }\end{array}$ & $\begin{array}{l}\text { Ketoconazole, itraconazole, } \\
\text { HIV protease inhibitors, } \\
\text { clarithromycin }\end{array}$ & $\begin{array}{l}\text { Increase } \\
\text { apixaban's } \\
\text { action }\end{array}$ & $\begin{array}{l}\text { Reduce dosage to 2.5 mg twice daily } \\
\text { or consider alternative anticoagulant }\end{array}$ \\
\hline
\end{tabular}


TABLE 4

Suggested anticoagulant dosing conversions

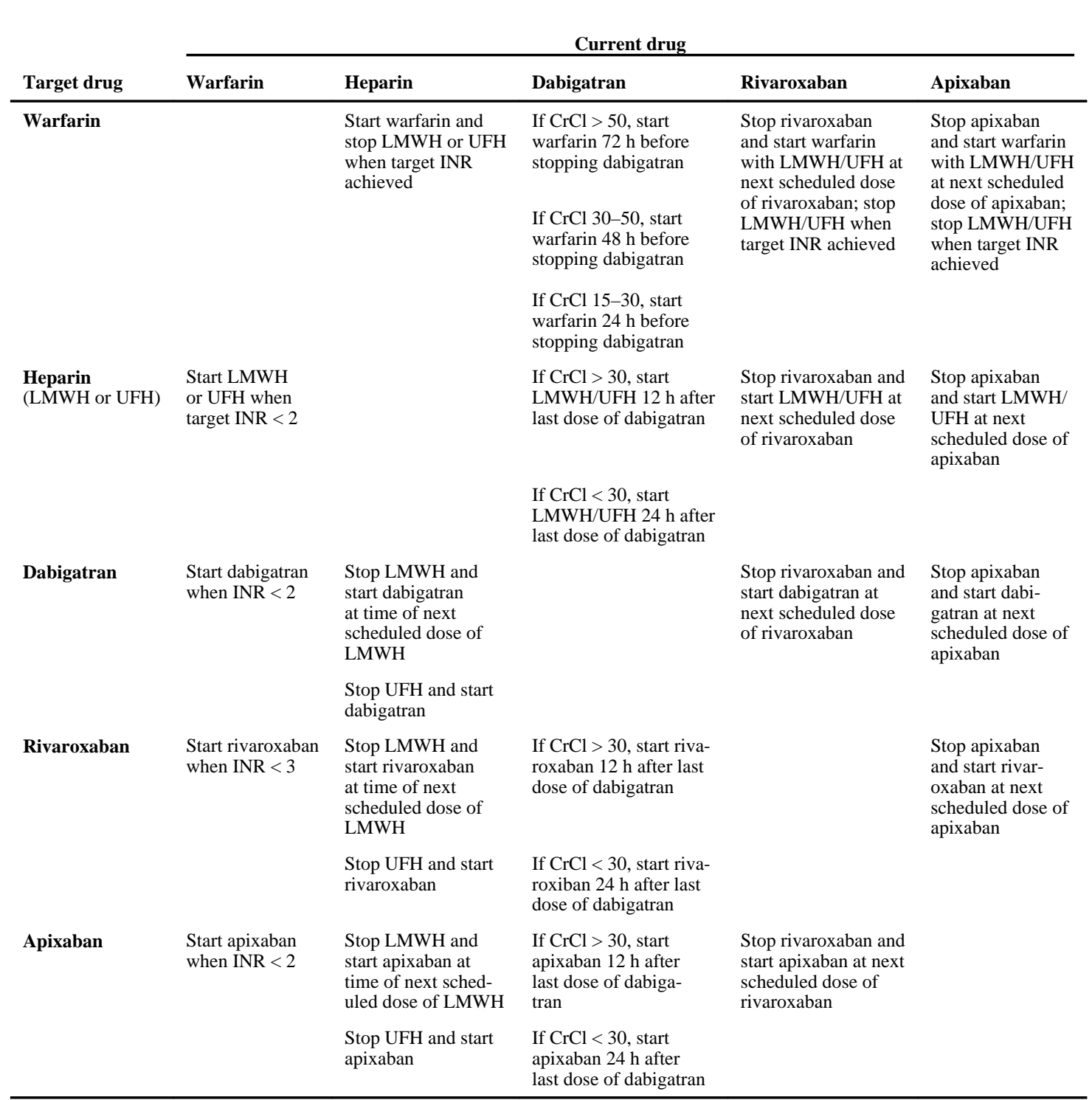

$\mathrm{CrCl}=$ creatinine clearance $(\mathrm{mL} / \mathrm{min}) ; \mathrm{INR}=$ international normalized ratio; LMWH = low-molecular-weight heparin $(\mathrm{LMWH}) ; \mathrm{UFH}=$ unfractionated heparin

INFORMATION ADAPTED FROM MPR (MONTHLY PRESCRIBING REFERENCE), ANTICOAGULANT DOSING CONVERSIONS. AUGUST 18, 2014. WWW.EMPR.COM/ANTICOAGULANT-DOSING-CONVERSIONS/ARTICLE/194271/. ACCESSED DECEMBER 9 , 2014. 
TABLE 5

Recommended antithrombotic therapy for patients with atrial fibrillation

\begin{tabular}{|c|c|c|}
\hline Condition & Recommended therapy & Target INR (range) $a$ \\
\hline \multicolumn{3}{|l|}{ Nonvalvular atrial fibrillation } \\
\hline With $\mathrm{CHA}_{2} \mathrm{DS}_{2}$-VASc score of 0 or $1^{b}$ & May omit antithrombotic therapy $c$ & \\
\hline With $\mathrm{CHA}_{2} \mathrm{DS}_{2}-\mathrm{VASc}$ score $=1$ & $\begin{array}{l}\text { Aspirin } 81 \mathrm{mg} / \text { day, warfarin, target-specific oral } \\
\text { anticoagulant } d \text { (TSOAC), or no therapy } c\end{array}$ & $2.5(2.0-3.0)$ \\
\hline With $\mathrm{CHA}_{2} \mathrm{DS}_{2}$-VASc score $\geq 2$ & Warfarin or $\mathrm{TSOAC}^{c}$ & $2.5(2.0-3.0)$ \\
\hline Hypertrophic cardiomyopathy & Warfarin or TSOAC $c$ & $2.5(2.0-3.0)$ \\
\hline Native valve disease $e^{e}$ & Warfarin $f$ & $2.5(2.0-3.0)$ \\
\hline $\begin{array}{l}\text { With systemic embolism with international } \\
\text { normalized ratio (INR) } 2-3\end{array}$ & $\begin{array}{l}\text { Warfarin or } \\
\text { warfarin + aspirin } 81 \mathrm{mg} \text { daily } f\end{array}$ & $\begin{array}{l}3.0(2.5-3.5) \\
2.5(2.0-3.0)\end{array}$ \\
\hline Bioprosthetic valve $g$ & Warfarin $f$ & $2.5(2.0-3.0)$ \\
\hline With systemic embolism with INR 2-3 & $\begin{array}{l}\text { Warfarin or } \\
\text { warfarin + aspirin } 81 \mathrm{mg} / \text { day } f\end{array}$ & $\begin{array}{l}3.0(2.5-3.5) \\
2.5(2.0-3.0)\end{array}$ \\
\hline Mechanical valve $h$ & Warfarin $c, f$ & $3.0(2.5-3.5)$ \\
\hline With systemic embolism with INR 2.5-3.5 & Warfarin with or without aspirin $81 \mathrm{mg} /$ day $f$ & $3.5(3.0-4.0)$ \\
\hline \multicolumn{3}{|c|}{$\begin{array}{l}a \text { For patients taking warfarin. } \\
\text { Female patients with sex alone being the only risk factor. }\end{array}$} \\
\hline \multicolumn{3}{|l|}{ Apixaban, dabigatran, rivaroxaban. } \\
\hline \multicolumn{3}{|c|}{ Includes hemodynamically significant rheumatic mitral stenosis or mitral valve prolapse. } \\
\hline
\end{tabular}


TABLE 6

Anticoagulant choice for special populations

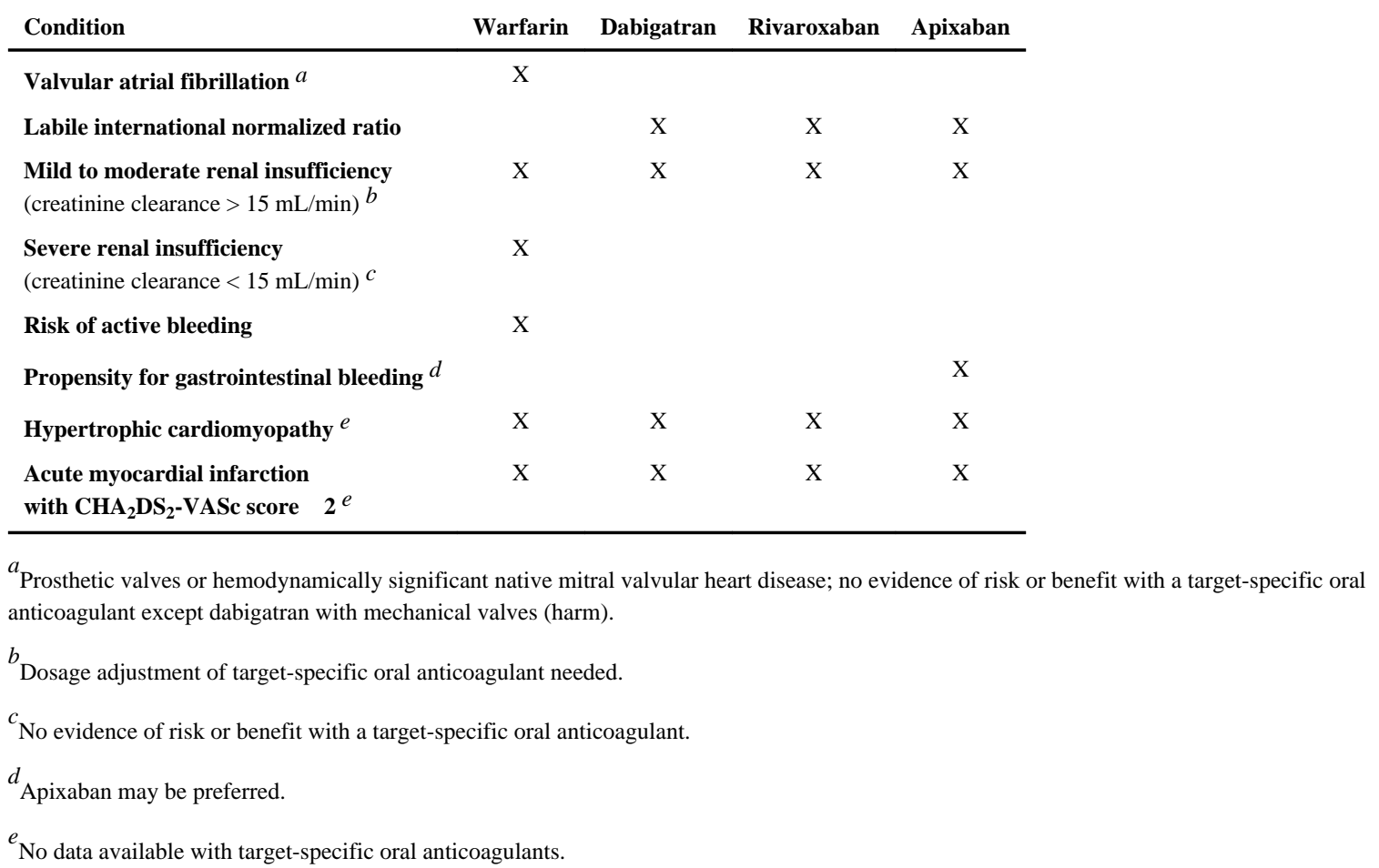




\section{TABLE 7}

Comparison of target-specific oral anticoagulants

\begin{tabular}{|c|c|c|c|}
\hline & Dabigatran & Rivaroxaban & Apixaban \\
\hline Mechanism & Direct thrombin inhibitor & Factor Xa inhibitor & Factor Xa inhibitor \\
\hline Metabolism & Renal $80 \% a$ & $\begin{array}{l}\text { Hepatic } 60 \%^{b} \\
\text { Renal } 30 \% a\end{array}$ & $\begin{array}{l}\text { Hepatic } 25 \% b \\
\text { Biliary and renal } 75 \% a\end{array}$ \\
\hline Plasma half-life & $12-17$ hours & $5-9$ hours & 9-14 hours \\
\hline Pivotal trial & RE-LY ${ }^{c}$ & ROCKET-AF $d$ & ARISTOTLE $^{e}$ \\
\hline Dose & $150,110 \mathrm{mg}$ twice a day & $\begin{array}{l}20 \mathrm{mg} \text { daily; } \\
15 \mathrm{mg} \text { daily if chronic kidney } \\
\text { disease }\end{array}$ & $\begin{array}{l}5 \mathrm{mg} \text { twice a day; } \\
2.5 \mathrm{mg} \text { twice a day if } 2 \text { of } 3 \\
\text { factors (creatinine } \geq 1.5 \mathrm{mg} / \mathrm{dL} \text {, } \\
\text { age } \geq 80 \text {, weight } \leq 60 \mathrm{~kg} \text { ) }\end{array}$ \\
\hline $\mathrm{CHADS}_{2}$, mean & 2.1 & 3.5 & 2.1 \\
\hline $\begin{array}{l}\text { Time in therapeutic } \\
\text { range (INR } \geq 2 \text { ) }\end{array}$ & $64 \%$ & $55 \%$ & $62 \%$ \\
\hline $\begin{array}{l}\text { Stroke, systemic } \\
\text { embolism, relative } \\
\text { risk ( } 95 \% \text { confi- } \\
\text { dence interval) }\end{array}$ & $\begin{array}{l}150 \mathrm{mg}: 0.65(0.52-0.81) \\
P \text { (noninferiority) }<.001 \\
P \text { (superiority) }<.001\end{array}$ & $\begin{array}{l}0.88(0.74-1.03) \\
P(\text { noninferiority })<.001 \\
P(\text { superiority })=.12\end{array}$ & $\begin{array}{l}0.79(0.66-0.95) \\
P(\text { noninferiority })<.001 \\
P(\text { superiority })=.01\end{array}$ \\
\hline Death, relative risk & $\begin{array}{l}150 \mathrm{mg}: 0.88, P=.051 \\
110 \mathrm{mg}: 0.91, P=.13\end{array}$ & $0.85, P=.07$ & $0.89, P=.047$ \\
\hline Adverse effects & $\begin{array}{l}\text { Dyspepsia, gastrointestinal } \\
\text { bleeding, risk of myocardial } \\
\text { infarction, } 150 \mathrm{mg} \text { : relative } \\
\text { risk } 1.38, P=.048\end{array}$ & $\begin{array}{l}\text { Gastrointestinal bleeding; } \\
\text { possible increase in thrombo- } \\
\text { embolism when held }\end{array}$ & \\
\hline Advantages & $\begin{array}{l}\text { Compared with warfarin: } \\
\text { reduction in risk of ischemic } \\
\text { stroke, trend toward reduction } \\
\text { in mortality risk }\end{array}$ & Once-daily dosing & $\begin{array}{l}\text { Compared with warfarin: } \\
\text { reduction in risk of stroke and } \\
\text { systemic embolism, reduction in } \\
\text { mortality risk }\end{array}$ \\
\hline Disadvantages & $\begin{array}{l}\text { Dyspepsia; possible risk of } \\
\text { myocardial infarction; twice- } \\
\text { daily dosing; no readily avail- } \\
\text { able reversing agent, but } 60 \% \\
\text { removed by dialysis }\end{array}$ & $\begin{array}{l}\text { Possible risk } \\
\text { of thromboem- } \\
\text { bolism when held; no readily } \\
\text { available reversing agent; } \\
\text { possible use of prothrombin } \\
\text { complex concentrate }\end{array}$ & $\begin{array}{l}\text { Possible risk of thromboembolism } \\
\text { when held; twice-daily dosing; no } \\
\text { readily available reversing agent; } \\
\text { possible use of prothrombin } \\
\text { complex concentrate }\end{array}$ \\
\hline
\end{tabular}

${ }^{a}$ Active drug excreted.

${ }^{b}$ Drug metabolized to inactive moiety.

$c_{\text {RE-LY }}=$ Randomized Evaluation of Long-term Anticoagulation Therapy (see references 45 and 46).

$d_{\text {ROCKET-AF }}=$ Rivaroxaban Once Daily Oral Direct Factor Xa Inhibition Compared With Vitamin K Antagonism for Prevention of Stroke and Embolism Trial in Atrial Fibrillation (see reference 53).

${ }^{e}$ ARISTOTLE $=$ Apixaban for Reduction in Stroke and Other Thromboembolic Events in Atrial Fibrillation (see reference 56). 